\title{
On the Circumstantial Context of J. S. Bach's Canon super Fa Mi BWV 1078
}

\author{
A. P. Milka ${ }^{1,2}$ \\ ${ }^{1}$ Saint Petersburg Rimsky-Korsakov State Conservatory, \\ 3, Teatralnaya sq., St. Petersburg, 190000, Russian Federation \\ ${ }^{2}$ St. Petersburg State University, \\ 7-9, Universitetskaya nab., St. Petersburg, 199034, Russian Federation
}

For citation: Milka, Anatoly. "On the Circumstantial Context of J. S. Bach's Canon super Fa Mi BWV 1078”. Vestnik of Saint Petersburg University. Arts 9, no. 2 (2019): 238-255.

https://doi.org/10.21638/spbu15.2019.202

As tentatively accepted by most twentieth-century J. S. Bach scholars, the dedicatee of Canon BWV 1078 might be Benjamin Gottlieb Faber, a physician with a musical background and a friend of Bach's student, copyist, and son-in-law, Johann Christoph Altnickol. The transparent encryption of Faber's name in the text of the canon is reflected in the sole corresponding reference in Bach's biography: B. G. Faber was the representative of the absent godfather (J. S. Bach) at the baptism of Johann Sebastian Jr., the son of Bach's daughter Juliane Friederica and her husband Johann Altnickol. This article substantiates the probability that B. G. Faber was indeed the dedicatee of Canon BWV 1078. I hypothesize that Bach's deteriorating health in the early autumn of 1748 , reflected in the sudden cancellation of his trip to Berlin to be godfather at the baptism of Carl Philipp Emanuel's son Johann Sebastian Jr., along with sudden changes in Bach's handwriting, indicate that he had most probably suffered a minor stroke that prevented him from traveling. The juxtaposition of the date of the canon's composition, with the date of birth of Altnickol's child, indicates that the announcement of Juliane's pregnancy and decision to ask B. G. Faber to represent the absent godfather could have taken place close to March 1, 1749, when J. S. Bach dedicated this canon to Faber and, by doing so, expressed his gratitude to his friend.

Keywords: Johann Sebastian Bach, Canon BWV 1078, dedicatee, Benjamin Gottlieb Faber, J. S. Bach's handwriting, J. S. Bach's illness, acrostic, paragram.

\section{Introduction}

On March 1, 1749, Johann Sebastian Bach wrote one of his so-called "album canons" (Stammbuchkanon), later known as Canon super Fa Mi, a 7, post Tempus Musicum (BWV 1078). Today this is generally assumedly to be associated with the name of the dedicatee, Benjamin Gottlieb Faber. A Stammbuch is an album or a book with memorial inscriptions provided by friends, guests, celebrities, etc., who contribute their intellectual offerings to the host. These could vary in form, but in Bach's milieu they were most often riddle canons, in which a composer would manifest the inventiveness of his mind. By doing so, he would also be courteously acknowledging the inventiveness of the recipient, who was supposed to decrypt its musical content, solve the enigma of its verbal expression,

${ }^{1}$ My deep thanks to Marina Ritzarev for our discussions in the process of translating this article and to Naomi Paz for her most delicate English editing.

(c) Санкт-Петербургский государственный университет, 2019 
and comprehend the overall meaning of such a sophisticated message. This constituted a good intellectual exercise, in addition to immortalizing the name of the dedicatee, who from that moment on would be associated with a famous composer whose aristocracy of spirit, even long before its nineteenth-century cultivation, was already noticeably in the air. As well, canons of this kind were usually heavily loaded with symbolism and contained some secret meaning relating to the merits of the album's possessor or to the relationship between him and the presenter of the gift.

While album canons belong to the genre of musical composition, this is not their sole purpose. Although they feature a musical text that can be played, the purely musical text is only one part of the composition. The verbal text too is usually, if not a major, at least an equal element of the puzzle canon. Hence, these works are not intended either for concert performance or for music-making, although their musical aspect is meaningful. It is not by chance that we will almost never find indications of the musical instruments to be used (with the small exception of cases in which this has a special significance): the principal instrument for performance of an album canon's musical text is intended to be the human inner ear. The musical layer of the composition is addressed, however, not only to the ear, but, even more, to the intellect of the individual who will interact with the composition in a kind of spiritual game. Therefore, it would be more accurate to talk about the notional nature of such opuses.

The canon under discussion stands out from similar canons in its complexity and a string of peculiarities. Its musical material is written as two visual units, seemingly not corresponding to one another musically or graphically: one has two measures of $2 / 2$ time, and the other has seven measures of $4 / 2$. Moreover, they are emphatically separated from one another by the title of the canon, which is located not above the musical text, as is usually the case, but in the middle, between these two components of musical content. Fig. 1 presents the copy of Canon BWV 1078 written by Bach's student Johann Philipp Kirnberger ${ }^{2}$. There is also a decryption of the canon on the verso of the sheet, written by the same student. Bach's autograph of the canon is lost. However, there is a consensus among scholars that the copy can be trusted as accurately conveying the original layout of Bach's composition. Hence, the above peculiarities, clearly seen in Fig. 1, must reflect Bach's notion of all of its components and their significance.

\section{General structure of the canon}

Before offering my interpretation of the contextual meaning of the canon and its addressee, I shall survey its elements from top down. The entire composition consists in six elements, alternating between verbal and musical texts. The first is the motto $\mathrm{Fa} \mathrm{Mi}$, et $\mathrm{Mi}$ Fa est tota Musica (fig. 2). The second component is the base of the canon: the two-measure cantus firmus accompanied by verbal text above and below the musical line (fig. 3). As the following musical text of the canon indicates, this four-note motif repeats 13 times, like an ostinato formula. Its two accompanying verbal lines present the first puzzle. The upper line is a letter notation of what we see in notes $F-A-B-E$, which, if we add the letter $R$ from the word Repetatur (repetition), reads FABER, in all probability indicating the name of the dedicatee. The lower line, at first glance, does not match the musical line and

${ }^{2}$ Reproduced with the kind permission from the Staatsbibliothek zu Berlin, Preussischer Kulturbesitz, shelf mark Mus. ms. Bach P 611. [For more details see 1, p. 90-2 and 2, p. 26-7]. 


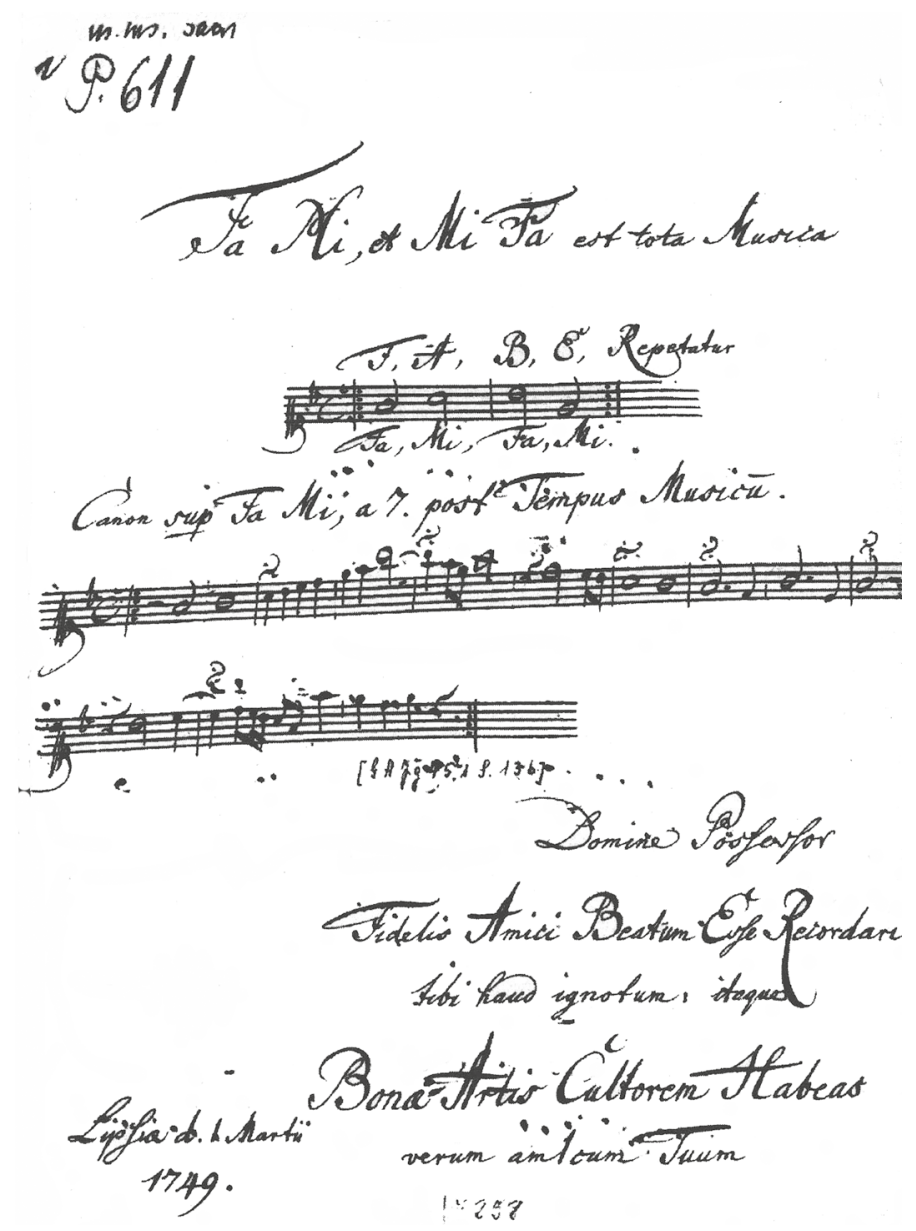

Fig. 1. Canon super Fa Mi a7 BWV 1078
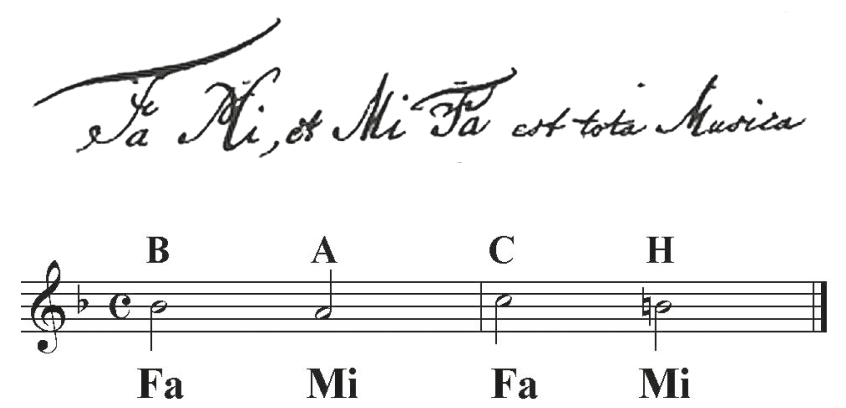

Fig. 2. Motto of the canon 


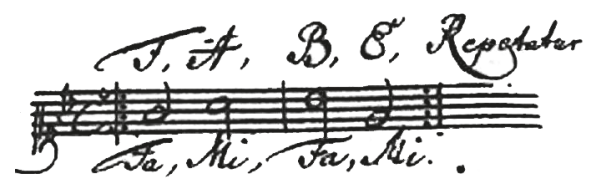

Fig. 3. The first musical line of the canon

appeals instead to the reader's background knowledge of the solmization system and its use of transposition. As noted first by Spitta, its $\mathrm{Fa}-\mathrm{Mi}$-Fa-Mi echoes $\mathrm{Fa} \mathrm{Mi}$, et $\mathrm{Mi} \mathrm{Fa}$ from the motto and $\mathrm{Fa} \mathrm{Mi}$ from the title, underlining the importance of this principal symbol of the canon.

Philipp Spitta wrote:

It is a canon in seven parts on a Basso ostinato $\mathrm{f}^{\prime} \mathrm{a}^{\prime} \mathrm{b}^{\prime} \mathrm{e}^{\prime}$. As these notes by the rules of solmization represent the syllables $f a m i$ twice repeated inasmuch as the two middle notes belong to the sixth hexachord and the others to the fifth, it was possible for Bach to say that the canon was written on the fa mi (or mifa) [3, p. 236].

While Spitta explains how the F-A-B-E sequence of notes can be translated to $\mathrm{Fa}-\mathrm{Mi}$ $\mathrm{Fa}-\mathrm{Mi}$, it cannot escape the reader that the discrepancy between $\mathrm{Fa}-\mathrm{Mi}-\mathrm{Fa}-\mathrm{Mi}$ of this line and $\mathrm{Fa} \mathrm{Mi}$, et $\mathrm{Mi} \mathrm{Fa}$ from the motto conceals certain issues that require resolution.

The third component is the title of the canon (fig. 4). The title Can[on] sup [er] Fa Mi, a 7. post Tempus Musicu[m] (Canon upon Fa Mi in 7 parts, at the distance of a full measure [translation borrowed from 3, p. 236]) tells us that we have a contrapuntal canon, which is a canon comprising a counterpoint to the cantus firmus. The keyword is super (above, beyond, over). The expression post Tempus Musicu[m] indicates that each of six rispostas should enter one brevis time after the preceding voice ${ }^{3}$.

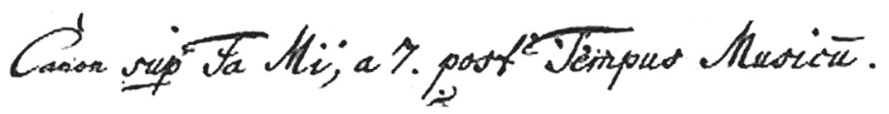

Fig. 4. Title of the Canon

The fourth component is the musical line featuring one voice and encrypting the entire canon as "seven in one" (fig. 5). As follows from the musical text, this seven-voice

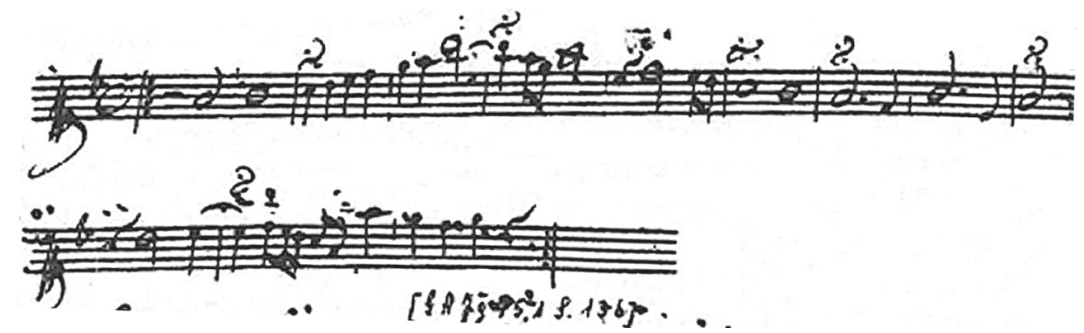

Fig. 5. The melodic line of the canon

3 Tempus is a term from the system of metrical organization in music that mostly developed in theory studies of the fifteenth and sixteenth centuries, and meaning time signature or a measure equal to brevis. Spitta explains: "Each of the parts of the canon enters a double bar (tempus musicum) after the foregoing part” [3, p. 238]. 
canon is formed by one proposta and six rispostas (indicated by six signs of segno / $/$ /). If we add to this the cantus firmus, we have an eight-part piece. The repeat signs at the beginning and at the end of the line tell us that this canon is infinite.

The fifth component is the dedication (fig. 6). Its text reads:

Domine Possessor

Fidelis Amici Beatum Esse Recordari

tibi haud ignotum: itaque

Bona Artis Cultorem Habeas

Verum amIcum Tuum

The translation reads:

Sir Owner, You hardly fail to know that to remember a faithful friend means happiness: accordingly take the cultivator of the good art as your true friend. (Translation borrowed from [4, p. 236]).

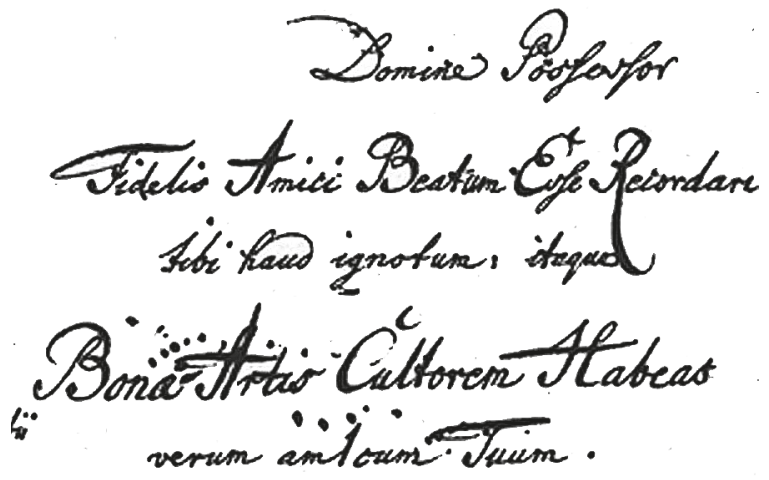

Fig. 6. Dedication

As can be seen from the use of capitalized letters in the text, this dedication employs the principle of an acrostic, thus multiplying the reference to the name of Faber and apposing it to the name of Bach.

The sixth component is an indication of the place and date of the composition's creation (fig. 7). The inscription reads: "Lipsia d. 1 Martii 1749" (Leipzig, March 1, 1749). This information is very important as we shall see further on. Note that in contrast to some

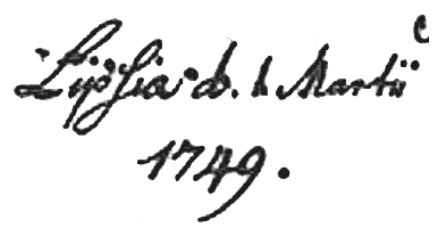

Fig. 7. Date and place of the composition's creation 
other album canons that have reached us in Bach's autographs, this canon does not have Bach's signature, instead featuring his name encrypted in the acrostic.

\section{Addressee}

The questions of the canon's addressee/dedicatee and its hidden circumstantial meaning have remained unsolved in Bach studies. With the increasing knowledge of the composer's biography and its context, however, new facts continue to surface, and new candidates appear for consideration.

The first to attempt to identify both the context and the person was Philipp Spitta, who considered that the circumstances surrounding the composition of the canon were associated with Bach's visitors, his well-known (or even famous) musician-friends: "It is to the visit of an illustrious musician that we owe a fine canon written by Bach in the last year but one before his death" [3, p. 237]. As for the addressee of the canon: "Who the individual may have been to whom Bach dedicated this work with its graceful arabesques can only be guessed" [3, p. 238]. By the time of Spitta's work, none of Bach's musician-associates were known to bear the name "Faber," and Spitta did not search for a possible candidate outside Bach's circle of professional musicians. Hence, Spitta resorted to the long-established tradition of the Latinization of names and found that Faber in Latin matched the German name Schmid (analogous to Smith). Smith (the profession) is only one in the list of synonyms for the Latin faber, which also include architect, artisan, carpenter, skillful, ingenious, etc., effectively connoting the image of a man of the arts. Spitta's approach was quite natural because all the inscriptions of this kind were written in Latin and there was no limit to the imagination of the puzzle canons' authors, who filled them with encrypted symbols.

The first of the possible candidates that Spitta suggested was Johann Balthasar Schmid (Schmied, Schmidt), one of Bach's students, the engraver and publisher of some of his works (Goldberg Variations, Canonic variations on the theme of the Christmas choral Vom Himmel Hoch). Balthasar Schmid had also participated in publication of the collection Clavierübung III). Spitta's arguments indeed have some merit ${ }^{4}$. According to Johann Nicolaus Forkel, quoting a letter by Carl Philipp Emanuel Bach, J. S. Bach's household thronged with guests and resembled a crowded dovecote ${ }^{5}$. This implies that anybody and everybody could be encountered there. Furthermore, Balthasar Schmid was quite a suitable candidate, one of Bach's renowned musician-friends. The common understanding of the circumstances surrounding the creation of Canon BWV 1078 is based on Spitta's study, who suggested that the occasion for composing this canon and the reason for its emergence was that of a visit to Bach's house by one of his famous friends (mostly musicians).

Later on, twentieth-century Bach scholars, among them Hans-Joachim Schulze and Werner Neumann, both of whom edited and commented in three basic volumes of BachDokumente, suggested new candidates for the role of this canon's dedicatee. The overall

${ }^{4}$ Friedrich Smend strengthened this hypothesis further, suggesting that the numerological meaning of the capitalized letters FABER.BACH $+\mathrm{I}$ and $\mathrm{T}$ in the last line of the acrostic are equal to the sum of the letters in the name SCHMIDT [5, p. 10-1; quoted by [6, p. 5-6].

${ }^{5}$ C. P. E. Bach wrote: "But he [J. S. Bach. - A. M.] had the more opportunity to talk personally to good people, since his house was like a beehive, and just as full of life. [4, p. 400] ("sein Haus einem Taubenhause u[nd] deßen Lebhaftigkeit vollkommen gliche") [7, III / 803, p. 290]. 
list of candidates suggested by Spitta [3, p. 237-8], Schulze [1, p. 90-2] and Wolff [2, p. 26, 35-7] is as follows:

- Johann Balthasar Schmid (1705-1749), J. S. Bach's student, engraver, and publisher;

- Johann Schmidt (1674-1746), J. S. Bach's student, an organist from Zella, Thuringia;

- Johann Christian Jacob Schmidt (1707-1768), the son of Bach's student Johann Schmidt;

- Johann Michael Schmidt (1728-1799) the author of Musico-Theologia (Bayreuth, 1754), in which he wrote about the great significance of J. S. Bach's late compositions, among them The Art of Fugue. In addition, on March 12, 1749 (a week and a half after the date of the canon's creation) he had received a bachelor's degree from Leipzig University;

- Benjamin Gottlieb Faber (1721-?) a friend of J. S. Bach's family. Graduated from Leipzig University, Faculty of Medicine, and a licentiate.

The first four individuals were musicians, to each of whom Bach could have been obliged for professional assistance. The fifth was a physician. Which of them was the dedicatee?

Today, all the candidates with the name Schmid (and variants of its spellingSchmied, Schmidt) have noticeably disappeared from mention, and there is an almost consensual opinion that Benjamin Gottlieb Faber is most likely to have been the one [1, p. 92]. There are, however, other individuals with the surname Faber who have also been considered. For example, Mary Greer hypothesizes that the dedicatee could have been B. G. Faber's namesake, Balthasar Faber [6]. Although offering many valuable insights and observations regarding this and another (BWV 1075) canons, her hypothesis still lacks factual connections between J. S. Bach and the young freemason, particularly in the absence of any masonry context in Bach's life, as well as the commonality of such basic masonic concepts as friendship and a cultivation of the arts being prevalent in the general values of the Enlightenment era.

In contrast to this, a very important connection associated J. S. Bach with Benjamin Gottlieb Faber, and this is the main point of the present article, which seeks to further substantiate a view of his candidature as the most plausible.

The importance of the dedicatee expresses itself in the entire text being replete with symbolism. Note that its verbal part is more developed than the musical one, although musical content too was not strange to Benjamin Gottlieb Faber. As Barbara Wiermann has established, B. G. Farber had once served as chorister, together with Johann Gottfried Fulde and Johann Christoph Altnickol, at St. Marie-Magdalene Church in Breslau [8]. All three had moved to Leipzig in 1743 and become part of Bach's circle. Their professional paths then split: Fulde studied theology, Faber studied medicine, and Altnickol studied music. Like Fulde, who became the dedicatee of the so-called "Fulde canon" BWV 1077 (October 15, 1747, Leipzig), Faber had at least a similar musical background, which made it possible for Bach to express his appreciation for Faber in his usual medium, even in such a sophisticated one as a puzzle canon. This circumstance negates a possible contradiction between B. G. Faber's being both a physician and a musician, as he possessed sufficient education to read and appreciate a precious message encrypted in the canon. 


\section{Symbolic expressions of Faber's and Bach's identities}

The beauty of a message was defined by a variety of symbolic artifices and codes that needed to match each other, displaying the correct proportions and symmetry, or what

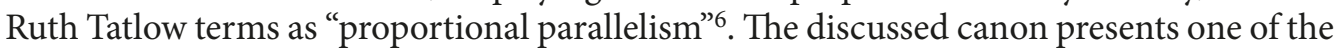
best examples of Bach's skills in composing such riddle messages.

The surname of the dedicatee, Faber, is quite visible in the text, while Bach's name is sometimes clear and sometimes more hidden. The most direct and clear presentation of Faber's name is found in the letter notation above the notes of the cantus firmus. As noted in the description of the general structure, the canon belongs to the kind of contrapuntal canons, which means a counterpoint to the previously presented cantus firmus, the "protagonist" of the entire composition. What serves as a cantus firmus is the motif $F-A-B-E$ ( $+R$ as indication of its repetition: Repetatur). This motif suggests (or hides?) the name of the canon's possessor (addressee/dedicatee).

There are additional encryptions indicating both identities (Faber and Bach) in more sophisticated ways. First among them is the motto FA MI, et MI FA est tota Musica: Fa Mi and $\mathrm{Mi} \mathrm{Fa}$ are the whole music (translation borrowed from [4, p. 236]), which opens the text of the canon. Variants of this motto can be found in many treatises of the Baroque era and even earlier. In treatises of later periods, they address not only intervals (semitone), but also major-minor harmony and, accordingly, appear similar in different sources. For example, the Anleitung zur Singekomposition by J. F. Kirnberger displays the inscription Fa $\mathrm{Mi}$, et Mi Fa est tota Musica over the four-part canon using the motif B-A-C-H. Another variant is in the well-known treatise Ut Re Mi, Re Fa La est tota Musica et harmonia eterna by Johann Heinrich Buttstett (1717), mentioned more than once in connection with the discussed canon (for example: [10, p. 359-60; 6, p. 14; 9, p. 13]).

The motto can be interpreted as an example of the general formula often present in inscriptions from the Baroque era:

$$
X+y \rightarrow \text { Totus mundus. }
$$

The $X$ and $Y$ here usually symbolize opposites, and, in their interaction, they encompass the entire world in a particular field of knowledge. In this motto, the two opposites are $\mathrm{Fa} \mathrm{Mi}$ and $\mathrm{Mi} \mathrm{Fa}$. The general message, thus, is a kind of gateway to the world of music. Indirectly, therefore, it relates to the master of this world, implying Johann Sebastian Bach.

The letter notation is used in its most typical function for Baroque music as a system of signification parallel to notes. It serves for encoding and decoding messages in compositions of such notional kinds as album canons and others. The puzzling textual line $\mathrm{Fa}-\mathrm{Mi}-\mathrm{Fa}-\mathrm{Mi}$ under the four notes of cantus firmus $\mathrm{F}-\mathrm{A}-\mathrm{B}-\mathrm{E}$, brings to mind the semitones reminiscent of the canon's motto $\mathrm{Fa} \mathrm{Mi}$ et Mi Fa est tota Musica, promoting the concept of the semitone as a foundational element of music, highly popular at the time. However, this phrase, in constituting a kind of variation of the motto, seems to relate to the purely

6 "Proportional parallelism would have seemed a self-evident practice to any composer living in Bach's time and locality, which is not to say that all composers used it. Symmetrical organisation, parallel techniques, perfect proportions and unity were all commonplace, were found in everyday life, in every academic discipline and creative pursuit, and were also described by music theorists in books about how to compose" [9, especially p. 6, 12-4]. 
aesthetic realm. It contributes little to decryption and eventually leads the reader to look for a possible paragram.

The paragram in Bach's music, as in his predecessors' and contemporaries' music, was a widespread and well-known phenomenon. The complex paragram encrypted in the musical text of Canon BWV 1078, however, necessitates recalling some general paragrammatic principles and their application in Baroque culture. Originating in the writings of the Holy Scripture's commentators, who sought to penetrate more deeply into the meaning of the holy texts, the paragram essentially presents a condition for equalizing the hidden meaning in a pair of messages possessing an identical gematrical index, be they in words, phrases, verses, chapters, or even entire parables from the Holy Scripture. Paragrams were considered as interlinked by means of a certain interconnection and being; not identical, but complementary. In this respect they could serve as certain surrogates (metaphors, analogues, or counterparts) of one another.

Fig. 8 and 9 present didactic German examples of paragrams in the Hebrew and the Latin alphabets. The first applies to the biblical text [11, p. 10; for its influence on Bach see 12] and the second, to German poetry [13, p. 72; for a description and analysis see 14, p. 76-82 and 162].

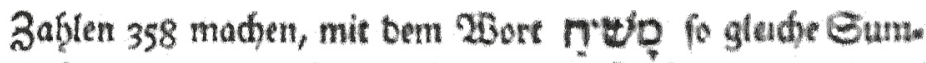 me bringt: Jmgleiden bas Wort nas Eath. 3, 8. mit onso ein Trófter, wethe bendetlen un Zablem 138 madien,}

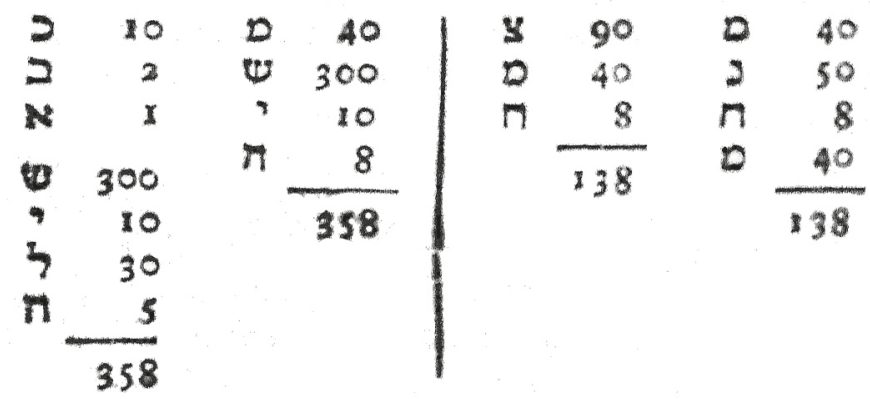

\section{So lange nun bergleidjen Erfinbungen fïr unberfängliobe}

Fig. 8. Johann Jacob Schmidt, treatise Biblischer Mathematicus (1736)

Regarding Canon BWV 1078, its paragram is encrypted in music, in two versions of the cantus firmus' letter notation, and later reflected, and in fact decrypted, in the acrostic of the dedication. Based on the acrostic revealing the names FABER and $\mathrm{BACH}$, one can also seek its encryption in the cantus firmus. While $F-A-B-E+R$ of the upper row is barely encrypted, the $\mathrm{Fa}-\mathrm{Mi}-\mathrm{Fa}-\mathrm{Mi}$ line, as noted above, offers only a hint.

The acrostic prompts us to look for the name Bach. Indeed, $B-A-C-H$ consists in two semitones, $B-A$ and $C-H$, and from a solmizational approach this presents the similarity with $\mathrm{Fa}-\mathrm{Mi}-\mathrm{Fa}-\mathrm{Mi}$ as much more compelling than the difference in their pitch relations. Thus, $\mathrm{Fa}-\mathrm{Mi}$ equalizes with both $B-A$ and $C-H$ :

$$
\mathrm{Fa}-\mathrm{Mi}=\mathrm{B}-\mathrm{A} \text { and } \mathrm{F} a-\mathrm{Mi}=\mathrm{C}-\mathrm{H}
$$


langend oie Babl ß3uchftaben auf nach gethento SBberfegefenet:

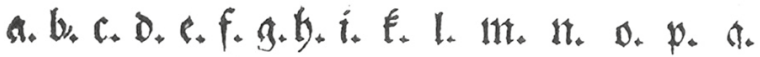
$I+2+3+4+5+6+7+8+9+10+I I+I 2+I 3+14+I 5+16$.

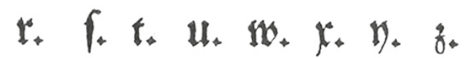

I7. I 8.19.20.2I+22.23+24,

SBann ich nuneiten Samen babe / fo finde

idh einen Sprudh/Derntit ocnfelben/glcicbe Zab"

lenfirbeet.

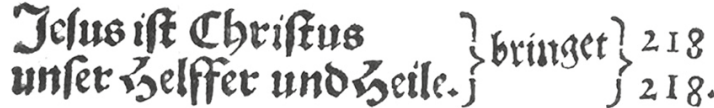

Goldbe gleichsablige sramen und Epriche verurfachen fu eigentlichen Erfindungen/ und

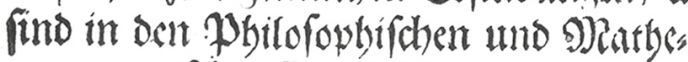

matifaben Erquicfitunoen su

feber.

Fig. 9. Georg Philipp Harsdörffer, treatise Poetischer Trichter (1653)

Since the $B A C H$ monogram was more than familiar in the composer's circle, the hint at his name was quite transparent. Moreover, it receives confirmation in the acrostic of the dedication. Note that the upper line accompanying the cantus firmus, $F-A-B-E+R$, corresponds to FABER in the upper line of the acrostic; while the bottom line of the cantus firmus $\mathrm{Mi}-\mathrm{Fa}-\mathrm{Mi}-\mathrm{Fa}$, which should be read as $B-A-C-H$, corresponds to the bottom line of the acrostic. We thus receive the following, given in fig. 10, ex. 1. In this case, the entire musical paragram resembles that in fig. 10, ex. 2 .
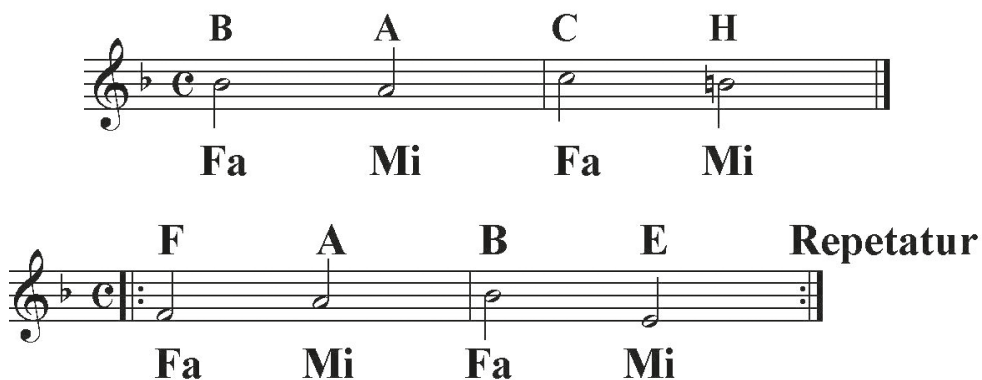

Fig. 10. The second part of the paragram

To express it gematrically, this time without the letter $\mathrm{R}$ and setting the sign of repetition :|| to zero, we receive:

$$
\begin{gathered}
\text { F A B } \quad \mathrm{E}: \|=\mathbf{1 4} \\
6+1+2+5
\end{gathered}
$$




\section{B $\mathrm{A}$ C $\mathrm{H}=14$}

$$
2+1+3+8
$$

As we can see, there is indeed a paragram, and it is obtained by way of decoding the mysterious inscription $\mathrm{Fa}-\mathrm{Mi}-\mathrm{Fa}-\mathrm{Mi}$ as a semitonal structure easily equalized with the semitonal structure of the name $\mathrm{BACH}$.

The acrostic is actually a decryption rather than an encryption, providing a key to Bach's name, sophisticatedly encrypted in the letters below the cantus firmus:

\section{Domine Possessor}

Fidelis Amici Beatum Esse Recordari

tibi haud ignotum: itaque

Bona Artis Cultorem Habeas

verum amIcum Tuum

In addition to the names of Faber and Bach revealed in the second and the fourth lines of the acrostic, there are also capitalized letters in the first and the fifth lines. The capital letters in the first line, Domine Possessor, constitute a standard address to a dedicatee, already familiar from Canon BWV 1077 composed for Faber and Altnickol's friend Johann Gottfried Fulde. Moreover, as can be seen in Kirnberger's copy, some of the capitalized letters of the acrostic, but not $D$ and $P$, appear to be marked by darker and thicker lines, which is also reflected in the publications ${ }^{7}$. This presents a certain ambiguity. On the one hand, the regular font of the letters $\mathrm{D}$ and $\mathrm{P}$ allows them not to be considered as belonging to the acrostic; but on the other hand, it is the capitalization of letters and not (or not only) their different font that refers to an acrostic. Hence, this first line comfortably remains in a gray zone between belonging and not belonging to the acrostic. Moreover, since the name of the dedicatee is represented in the acrostic, this formal address may not be necessary at all.

Another issue pertains to the last line, in which the letters $\mathbf{I}$ and $\mathbf{T}$ are not only clearly marked by color and width, but the letter $\mathbf{I}$ is capitalized in the middle of a word, which was not at odds with the codes of Baroque expression, though clearly not the happiest of Bach's solutions, in contradicting his striving for perfection. Spitta defined the letters I and $\mathrm{T}$ as signifying Bach's birthplace in the Latin form: Isenaco-Turingum. While Spitta's interpretation has been mostly accepted by scholars, including the present author, the fact of Bach's reference to his own birthplace raises some questions in the context of the acrostic.

Considering the perfectly symmetrical presentation of both names, FABER and $\mathrm{BACH}$, in the second and fourth lines of the five-line dedication, the indication of only Bach's birthplace and, moreover, in an obviously forced and awkward form, breaks the symmetry and contradicts the emphatically friendly expression of Bach's relationship to Faber. The entire construction of the acrostic thus looks awry, making this line seem unnecessary. To recall, various definitions of an acrostic state that the importance of the letters comprising the acrostic should be marked not so much by their capitalization, as by their location as opening (or closing lines), and in any case as initial letters (the Ancient Greek word ákros in itself means extremity). In this case, as in some other inscriptions,

7 The capitalized letters of the acrostic were first printed in bold style by Spitta [15, p. 717], in which the letters $\mathrm{D}$ and $\mathrm{P}$ in the first line were printed in semi-bold. Later, in the BG [16, p. 136] - these letters were printed in regular font, while all the other acrostic letters are in bold. 
Bach capitalized the letters of all the words within a line, whereas capitalization of a letter within a single word, and for such a dubious purpose as to indicate his own birthplace by any means, seems to be an unjustified distortion of an otherwise beautiful acrostic. The Latin language, the acrostic, and the content of the dedication do not match as perfectly as Bach's taste would seem to demand-unless this forced action was the result of some necessity, possibly due to its symmetrical correspondence to the other elements of the text that were intended to relate to the identity of Faber. What remains to be unraveled is the first line of the dedication.

An awareness of Bach's attention to both a well-shaped outline of his inscriptions and a highly developed decorum, makes it highly unlikely that he meant the first line of the dedication to be read as it is today: as a casual address, unrelated to the acrostic. In search of the answer to this controversy, a closer examination of the first line, Domine Possessor, is required, even if the first letters of its two words should necessarily be capitalized. This is because the first word opens the address, and the second one signifies the status of the addressee, as they do in the Fulde canon.

Looking for symmetry, it would be logical to suggest that these letters could relate to the birthplace of Benjamin Gottlieb Faber. Although this cannot be proven at the moment due to a lack of reference to the source at hand, it is worth paying attention to these letters' correspondence with Faber's native town of Dolne (in the eighteenth-century map, although mostly known today as Brzeg Dolny) in Poland, in the vicinity of Breslau (Wroclaw, Bratislava). The geopolitical affiliation of this south-western Silesian town fluctuated between Poland and Germany. Since 1742, it had been in German possession and the toponym was Dyhernfurth, Prussia (Lat. Prussia), whose first letters $P$ and $D$ remarkably coincide with Dolne, Poland (Lat. Polonia). Considering the Domine Possessor line, the coincidence is triple, and this would hardly have escaped Bach. Thus, both these seemingly unnecessary lines-the bottom indicating only Bach's birthplace, and the upper as a formal address-acquire their logical justification in the symmetry of their meaning.

The acrostic, with its symmetry, reflects the symmetry of the paragram. This elevated the status of the dedicatee to that of the composer. The acrostic's wording in both Faber's and Bach's parts, twice mentions a faithful friend: Fidelis Amici and verum amIcum. Linking his own name with that of a cultivator of the fine arts (Bona Artis Cultorem Habeas) ${ }^{8}$, the great composer modestly introduced himself as just another representative of another guild and, by doing so, seemingly elevates Faber to the rank of an arts connoisseur. If we compare this canon with the Fulde canon, however, although both dedicatees apparently belong to the same category of Altnickol's friends (within Bach's circle), we see a major difference. Although the Fulde canon does include symbolism referring to the dedicatee's theological occupation, it offers neither a paragram, nor an acrostic, nor Fulde's name.

Bach's intellectual efforts invested in the construction of a sophisticated paragram and acrostic, as well as a flattering dedication, attest to the high importance of the person to whom this gift canon was addressed.

The place and date of the canon are Leipzig, 1 March 1749. This is the only nonartistic element of the canon, and bears no symbolism. The next date we know, however, as being associated with Faber, is October 6 of the same year 1749, when Benjamin Gottlieb Faber would be present at the baptism of Bach's grandson in Naumburg. A connection

\footnotetext{
${ }^{8}$ Noted by Benjamin Shute [17, p. 118-9].
} 
between these two dates has long since been noticed and serves as grounds for a tentative attribution of the canon to B. G. Faber. No other biographical context explaining this connection, however, is available. For this, we must go back around six months, to the end of August or the beginning of September 1748.

\section{Illness}

Some scholars have pointed out that by autumn (or early autumn) of 1748 , the deterioration in Bach's health had become noticeable. Peter Williams wrote:

In writing that the surgery and subsequent treatment overthrew his whole system, Emanuel speaks as if an eye-witness to Bach's last six months. But there is no certain evidence for this, and the final period of discomfort was probably nearer three months. Signs of deterioration in the handwriting from Autumn 1748 on, and certainly by December 1749, have been interpreted as indicating eyesight and other problems due to advanced diabetes [18, p. 53-64], chronic rather than acute, exacerbated by age, and no doubt eventually worsened by the surgery and the subsequent debility or actual infections, as a source earlier than the Obituary claims [7, II / 264, p. 470]. There is room for doubt on each of these points, however [19, p. 266].

Yoshitake Kobayashi contested this view, arguing that while he connected Bach's deteriorating health with worsening handwriting, he saw the cause not in an ophthalmological disease, but in other factors:

The correctness of the widespread opinion that Bach had begun to write the clumsy script because of his eye disease is to be doubted. Rather, the cause of the awkward writing should be seen in the disabilities of the hand that are thought to be caused by an illness 9 .

Peter Wollny offers a more precise view:

In his last two years of life, Bach's disease perhaps progressed in the early autumn of $1748-$ accompanied by a deterioration in his handwriting"10.

At the same time, there are grounds to suppose that Bach's state of health was more serious than just a progressive illness; being, rather, a minor stroke (TIA) that he experienced but that did not cause him to stop his activity. What is especially important in Wollny's observation is the suddenness of Bach's deteriorating health. This was not gradual, as has usually been thought based on an understanding of his condition as a stereotypical progression of chronic diabetes and/or blindness. Wollny's view is confirmed by the sudden changes in Bach's handwriting. At the same time, remarkably and misleadingly, there is not a single documented piece of evidence in Bach's biography of any kind of disease at the beginning of autumn 1748. He was working as usual and did not change his routine way of life or activity other than the cancellation of his trip to Berlin. Indeed, his work was as intensive as ever. Thus, on August 20, he received an urgent commission to write a cantata for the ceremony of elections to the Municipal Council [7, II / 264, p. 194]. In less than a week, on August 26, the cantata Lobe den Her-

9 "Die Richtigkeit der verbreiteten Meinung daß Bach aufgrund seiner Augenkrankheit begonnen habe, die klobige Schrift zu schreiben, ist zu bezweifeln. $\langle\ldots\rangle$ Vielmehr ist die Ursache für die ungelenke Schrift in Beeinträchtigungen der Hand zu suchen, die vermutlich durch eine Krankheit verursacht werden sind" [20, p. 24].

10 "Bach mag in seinen beiden letzten Lebensjahren vielleicht nach einem-an einer spürbaren Verschlechterung der Handschrift abzulesenden-Krankheitsschub im Früchherbst 1748” [21, p. 42]. 
rn, meine Seele BWV 69 had been written, rehearsed, and performed. During this same period, August 1748, Bach began to scribe a grandiose project, an expanded part of his Mass in B minor BWV 232 (Symbolum Nicenum, Sanctus, Osanna, Benedictus, Agnus Dei, Dona nobis pacem) [22, p. 89].

Bach's letters, however, tell another story. In his letter of July $31,1748^{11}$ [7, I / 48, p. 114-5] (see: fig. 11), Bach's handwriting shows that at this time there were no signs of health problems, at least regarding the brain functions directly responsible for handwriting. We see here a full contact of quill with paper, full pressure control, distinct outlines of curves, a balance between flexor and extensor movements, a high degree of connectivity, a confident outline of the looped elements of the letters, clear horizontal orientation in writing, and so on. Very soon afterwards, however, Bach's handwriting featured changes, reflecting symptoms of a disturbance in the blood supply to the brain, as can be clearly seen in his letter (fig. 12) of October 6, $1748^{12}$ [7, I / 49, p. 117-8]. Here, a disturbance of the quill's contact with the paper is clearly seen, as well as uneven pressure ${ }^{13}$. In addition, there are unbalanced flexion-extension movements due to a weakening of the latter ${ }^{14}$, a lessened

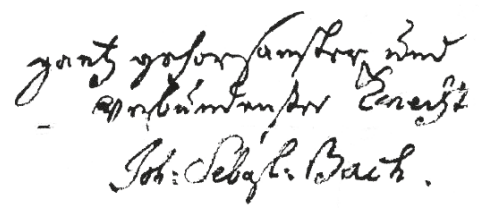

Fig. 11. Bach's letter of recommendation for Altnickol from July 31, 1748

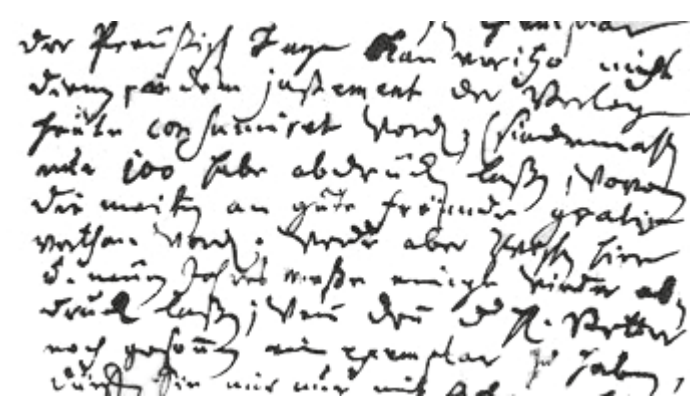

Fig. 12. J. S. Bach, letter to Johann Elias Bach of October 6, 1748

11 The facsimile reproduction can be seen in [22, p. 89 and 23, p. 36].

12 The facsimile reproduction can be seen in [23, p. 38].

13 This manifests in the writing of the letters (and their elements) in different thicknesses, as well as in the general increase in the "bold" lines, since when the contact between quill and paper weakens, the writer reflexively increases the pressure. This reaction is one of the indicators of a problem with blood supply to the brain.

${ }^{14}$ In this letter, the tendency to shorten the elements of letters written using extensor movements (in contrast to those written using flexors) can be observed. For example, in the Gothic writing of the letter d, its ascending element, using the extensor movement, is shortened, hence the letter becomes lower in the line, compared to the usual handwriting (see, for example, the word der in the second line of fig. 12). The difference can be easily seen if we compare this outline to that of the words und and verbundenfter in fig. 11. 
degree of connectivity ${ }^{15}$; reduced outline of curves (for example in the letter $\left.S\right)^{16}$, and reduced looped elements (for example in digraph $\left.\int t\right)^{17}$. There are additional signs attesting to a disturbance in the brain functioning responsible for motor activity. The above-noted signs demonstrate a standard manifestation of stroke-related changes. The most compelling circumstance is that these changes did not make their appearance gradually over the course of many months or even years, but happened suddenly and simultaneously.

As noted above, while on July 31, 1748 no health problems were evident, on September 26 Bach was not able to travel to his son Emmanuel in Berlin for the baptism of his grandson, although only a year earlier he had managed to travel easily to Potsdam to improvise before the King ${ }^{18}$. It is thus plausible that the problem with his health occurred between August 1 and September 26.

A juxtaposition of data derived from the handwriting in the letters of this period, as well as such facts taken from his biography as this being a period of uninterrupted intensive work, allow us to state with a certain amount of confidence that what had happened to Bach within that time-frame was a minor stroke (TIA). The attack probably happened at home, and for some time, at least until spring 1749, it was hidden from the public. The outrageously humiliating episode, when from 2-6 June the Leipzig magistrate organized an audition for Bach's substitute, Gottlob Harrer, while the great composer himself was still alive and active, was probably provoked by one of the following TIAs occurring in public.

According to further changes in the handwriting in his letters from a later period (for example to Johann Elias Bach, October 6, 1748 and the recommendation letter for Johann Nathanael Bammler, April 12,1749, as well as the later ones), the situation did not improve, and the disease progressed. How all this is related to Canon BWV 1078 can be seen from the chronology of certain family events that required Bach's presence.

\section{Chronology of events}

The sequence of events that occurred from August-September 1748 on is as follows: August-September 1748: Bach, as discussed above, probably suffered a minor stroke.

September 22: The birth of Carl Philipp Emanuel Bach's son, named Johann Sebas$\operatorname{tian}^{19}$.

September 26: Baptism of Johann Sebastian Bach Jr. The godfathers were comprised exclusively of high-ranking individuals, among whom, for example, the Russian Ambassador to Dresden, Count von Keyserling, was not the most important person ${ }^{20}$. J. S. Bach

15 In the first letter, Bach was still connecting many letters in the word (see the fragment in fig. 11 and the entire letter), but in the second one, the word Freünde, for example (fig. 12, the fifth line), is written with spaces separating each letter.

${ }^{16}$ Compare the outline of the letter $S$ in the first letter (the word Sebaft.) to that in the second one (the words consuniret and sindemahlen).

${ }^{17}$ Compare the writing of the digraph $\int t$ in the first letter (the words verbundenfter and Sebaft.) to that in the second one (the words juftement and meiften).

18 As soon as it was decided to give the newborn grandson the name of his grandfather, Johann Sebastian Jr., according to tradition, the composer had to be present at the baptism ceremony.

19 The date is established by J. S. Bach's letter of October 6, 1748 (to his Schweinfurt cousin Johann Elias Bach), in which he wrote about his new grandson that "he is just 14 days old" (ist etwa 14 Tage alt) [7, I / 49, p. 118]. This means that he was born on September 22.

20 The Paten list consisted in seven people (in contrast to the usual three or four): 1 . His Highness Heinrich, Margrave of Brandenburg-Schwedt, His Highness Karl, Margrave of Brandenburg-Schwedt (co- 
could not attend the event. This caused at least two disturbances during the ceremony: first, the date of the baptism was delayed by four days, although usually taking place on the second day, or even on the very day of the birth ${ }^{21}$; and second, no one had been appointed to substitute for J. S. Bach at the ceremony ${ }^{22}$.

On December 19, 1748, J. S. Bach's daughter Elizabeth Juliana Friederica ("Lizchen") and his student and copyist Johann Christoph Altnickol became engaged, which was announced in Leipzig, close to Christmas [7, II / 576, p. 451-2]. A week later, on December 26, 1748, the announcement of the engagement was made in Naumburg, where Altnickol was already working as an organist at the Wenzelskirche since September 1748 [7, II / 578, p. 453].

January 4, 1749: An invitation to the wedding in Leipzig was sent to the Municipal Council of Naumburg [7, II / 579, p. 453].

January 20, 1749: Wedding of Juliana Friederica Bach and Johann Christoph Altnickol in Thomaskirche [7, II / 579a, p. 454].

Moreover, from the end of February 1749 other quite significant events were taking place. By this time Juliana Friederica must have already been about 8-9 weeks pregnant, because there remained 31-32 weeks (of the usual forty) until she gave birth on October 4. At some point between wedding and childbirth, the young couple had to move to Naumburg. The awareness of Juliane's pregnancy and the probability that it could be a son whom the parents would also wish to name Johann Sebastian (as had Carl Philipp Emanuel in honor of the famous grandfather), posed for J. S. Bach a situation similar to that in the previous September when he had been unable to attend Carl Philipp Emanuel's son's baptism. This time, however, it was clear that Bach's trip could not be planned, even if Naumburg was very much closer to Leipzig than Berlin. This meant that the person who would replace Bach at the baptism ceremony needed to be appointed beforehand.

To continue the chronology of events, on October 4, 1749, Monday, 11:00 AM, in Naumburg, the first child of the Altnickols was born [7, II /587, p. 459]. Two days later, on October 6,1749, he was baptized and named Johann Sebastian. The grandfather, J. S. Bach, was absent and substituted by Benjamin Gottlieb Faber as the godfather's deputy [Ibid.].

\section{Conclusion}

The end of February 1749 was thus an appropriate time to request Benjamin Gottlieb Faber to represent J. S. Bach at the baptism ceremony. Being not only a friend of Johann Christoph Altnickol, but also a physician (currently completing his five-year period of

governor), His Excellency Minister von Happé, His Excellency Count Hermann Karl von Keyserling, as well as the spouse of General von Meyer and the wife of the military adviser, the knight of the Order of St. Juber and the deputy of the City Council, Mr. von Printz [24, p. 133].

21 There was no fixed date, but since the name was given to the newborn at the time of baptism, this was usually performed without delay. All the children of J. S. Bach had been baptized within the usual 1-2 days after birth. The delay in the baptism of Johann Sebastian, Jr., may have been due to the impossibility of the great composer arriving for the procedure in Berlin.

22 According to tradition, if the arrival of the godfather was impossible, a trustee replacing him (stat [ $t$ ] deßen, Vertreter) should have been appointed. However, because of the subtleties of court etiquette, or the order of ranking, or due to the difficulties and confusion associated with J. S. Bach's failure to arrive, no one had been appointed and the baptism suffered some procedural disruption. 
study and expecting to receive his degree on September 6, 1749), who could also supervise the labor, Faber was the ideal candidate for this honorable role, and the person to whom J. S. Bach entrusted his beloved family. Performing such an important role as a substitute godfather to Bach's grandchild, and namesake Johann Sebastian, would have somewhat equalized their names in a metaphorical paragram of life. In all probability, J. S. Bach's deep respect for this man and his gratitude to him found their sophisticated expression in the precious gift, in which he united their names and immortalized Benjamin Gottlieb Faber's name next to his own.

\section{References}

1. Schulze, Hans-Joachim. "Johann Sebastian Bachs Kanonwidmungen”. Bach-Jahrbuch 53 (1967): 82-92.

2. Bach, Johann Sebastian. Neue Ausgabe Sämtlicher Werke. Serie VIII: Kanons, Musikalisches Opfer, Kunst der Fuge. 3 Bände. Kritisches Bericht von Christoph Wolff. Kassel, u. a.: Bärenreiter, 1976, Bd. 1.

3. Spitta, Philipp. Johann Sebastian Bach: His Work and Influence on the Music of Germany, 1685-1750. Translated from German by Clara Bell and John Alexander Fuller-Maitland. 3 vols. London: Novello, Ewer \& Co., 1885, vol. 3.

4. David, Hans Theodore, and Arthur Mendel, eds. The New Bach Reader: A life of Johann Sebastian Bach in letters and documents. Revised and expanded by Christoph Wolff. New York; London: W. W. Norton \& Company, 1998.

5. Smend, Friedrich. Joh. Seb. Bach Kirchen-Kantaten Christlicher. Berlin: Christlicher Zeitschriftenverlag, 1950.

6. Greer, Mary. "Masonic Allusions in the Dedications of Two Canons by J. S. Bach: BWV 1078 and 1075". Bach 43, no. 2 (2012): 1-45.

7. Bach-Archiv Leipzig. Bach-Dokumente, Supplement zu NBA. 3 Bände. I: Neumann, Werner, und Hans-Joachim Schulze, Hrsg. Schriftstücke von der Hand Johann Sebastian Bachs. Kassel: Bärenreiter, 1963. II: Neumann, Werner, und Hans-Joachim Schulze, Hrsg. Fremdschriftliche und gedruckte Dokumente zur Lebensgeschichte Johann Sebastian Bachs 1685-1750. Kassel: Bärenreiter, 1969. III: Schulze, Hans-Joachim, Hrsg. Dokumente zum Nachwirken Johann Sebastian Bachs 1750-1800. Kassel: Bärenreiter, 1969.

8. Wiermann, Barbara. "Altnickol, Faber, Fulde - drei Breslauer choralisten im Umfeld Johann Sebastian Bachs". Bach-Jahrbuch 89 (2003): 259-65.

9. Tatlow, Ruth. Bach's Numbers: Compositional Proportion and Significance. Cambridge: Cambridge University Press, 2015.

10. Chafe, Eric. "Allegorical Music: The 'Symbolism' of Tonal Language in the Bach Canons”. The Journal of Musicology 3, no. 4 (1984): 340-62.

11. Schmidt, Johann Jacob. Biblischer Mathematicus, oder Erläuterung der Heil. Schrift aus den Mathematischen Wissenschaften $\langle\ldots\rangle$. Züllichau: Waysenhaus, 1736.

12. Meyer, Ulrich. "Johann Jacob Schmidts 'Biblischer Mathematicus' von 1736 und seine Bedeutung für das Verständnis der Zahlensymbolik im Werk J. S. Bachs". Die Musikforschung 32, H. 2 (1979): 150-3.

13. [Harsdörffer, Georg Philipp]. Poetischer Trichter. Die Teutsche Dicht- und Reimkunst, ohne Behuf der Lateinischen Sprache, in VI Stunden einzugießen. Nürnberg: Gedruckt bey Wolfgang Endter, 1653.

14. Tatlow, Ruth. Bach and the Riddle of the Number Alphabet. Cambridge: Cambridge University Press, 1991.

15. Spitta, Philipp. Johann Sebastian Bach. 2 Bände. Leipzig: Breitkopf \& Härtel, 1880. Band 2 (Book V$\mathrm{VI})$.

16. Bach-Gesellschaft zu Leipzig. Johann Sebastian Bachs Werke. Hrsg. Alfred Dörffel. 50 Bde. Leipzig: Breitkopf \& Härtel, 1897, Bd. 45.1.

17. Shute, Benjamin. Sei Solo: Symbolum? The Theology of J. S. Bach's Solo Violin Works. Eugene: Pickwick Publications, 2016.

18. Kranemann, Detlev. "Johann Sebastian Bachs Krankheit und Todesursache - Versuch einer Deutung”. Bach-Jahrbuch 76 (1990): 53-64.

19. Williams, Peter. J. S. Bach: A Life in Music. Cambridge: Cambridge University Press, 2007. https:// www.cambridge.org/core/books/j-s-bach/27524D4FD6E3482D165D64CC6CC33586. 
20. Kobayashi, Yoshitake. "Zur Chronologie der Spätwerke Johann Sebastian Bachs Kompositions- und Aufführungstätigkeit von 1736 bis 1750”. Bach-Jahrbuch 74 (1988): 7-72.

21. Wollny, Peter. "Neue Bach-Funde". Bach-Jahrbuch 83 (1997): 7-50.

22. Bach-Archiv Leipzig. Kalendarium zur Lebensgeschichte Johann Sebastian Bachs. Hrsg. Andreas Glöckner. Erweiterte Neuausgabe Herausgegeben. Leipzig: Evangelische Verlagsanstalt, 2008.

23. Ludewig, Reinhard. Johann Sebastian Bach im Spiegel der Medizin. Leipzig: Waechterpappel, 2000.

24. Miesner, Heinrich. "Aus der Umwelt Philipp Emanuel Bachs". Bach-Jahrbuch 34 (1937): 132-43.

Received: November 28, 2018

Accepted: February 21, 2019

Author's information:

Anatoly P. Milka — Dr. Habil., Professor; milka1939@mail.ru 